\title{
Fucoidan inhibits proliferation of the SKM-1 acute myeloid leukaemia cell line via the activation of apoptotic pathways and production of reactive oxygen species
}

\author{
CHUNMEI WEI, QING XIAO, XINGYI KUANG, TAO ZHANG, ZESONG YANG and LI WANG \\ Department of Hematology, The First Affiliated Hospital of Chongqing Medical University, \\ Chongqing 400016, P.R. China
}

Received October 24, 2014; Accepted July 23, 2015

DOI: $10.3892 / \mathrm{mmr} .2015 .4252$

\begin{abstract}
Myelodysplastic syndromes (MDS) are a heterogeneous group of myeloid disorders characterized by peripheral blood cytopenias and a high risk of progression to acute myeloid leukaemia (AML). Fucoidan, a complex sulphated polysaccharide isolated from the cell wall of brown seaweeds, has recently attracted attention for its multiple biological activities and its potential as a novel candidate for cancer therapy. In the present study, the anti-cancer activity of fucoidan was investigated in the MDS/AML cell line SKM-1. Fucoidan inhibited proliferation, induced apoptosis and caused G1-phase arrest of the cell cycle in SKM-1 cells as determined by a cell counting kit 8 assay and flow cytometry. Furthermore, reverse transcription quantitative polymerase chain reaction and western blot analyses indicated that treatment with fucoidan $(100 \mu \mathrm{g} / \mathrm{ml}$ for $48 \mathrm{~h})$ activated Fas and caspase-8 in SKM-1 cells, which are critical for the extrinsic apoptotic pathway; furthermore, caspase- 9 was activated via decreases in phosphoinositide-3 kinase/Akt signaling as indicated by reduced levels of phosphorylated Akt, suggesting the involvement of the intrinsic apoptotic pathway. In addition, fucoidan treatment of SKM-1 cells resulted in the generation of reactive oxygen species (ROS) as determined by staining with dichloro-dihydro-fluorescein diacetate. These results suggested that the mechanisms of the anti-cancer effects of fucoidan in SKM-1 are closely associated with cell cycle arrest and apoptotic cell death, which partly attributed to the activation of apoptotic pathways and accumulation of intracellular ROS. Our results demonstrated that Fucoidan inhibits proliferation and induces the apoptosis of SKM-1 cells, which provides substantial therapeutic potential for MDS treatment.
\end{abstract}

Correspondence to: Dr Li Wang, Department of Hematology, The First Affiliated Hospital of Chongqing Medical University, 1 Youyi Road, Chongqing 400016, P.R. China

E-mail: liwangls@yahoo.com

Key words: fucoidan, SKM-1 cells, cell proliferation, cell apoptosis, phosphoinositide-3 kinase/AKT, reactive oxygen species

\section{Introduction}

Myelodysplastic syndrome (MDS) is a heterogeneous group of clonal and potentially malignant bone marrow disorders characterized by ineffective, inadequate haematopoiesis in one or more of the lineages of the bone marrow (1). It has a variable propensity of transformation to acute myeloid leukaemia (AML) (2) and is described as a 'pro-leukaemia state' (3). MDS can arise de novo or as a consequence of previous chemo- or radiotherapy in cancer patients (4). It occurs most frequently in aged populations with a median age of 65-70 years at diagnosis (2). However, there is a paediatric population of MDS patients in which inherited bone marrow-failure syndromes are associated with high-risk factors. The median survival time of MDS patients following diagnosis is $0.5-6$ years $(5,6)$. Numerous types of therapy for MDS have been developed based on the molecular mechanisms of the diseases; for example, inhibitors of DNA methylation have been proven effective in the treatment of patients with MDS (7). Although available treatments have alleviated MDS-associated symptoms of certain patients, few treatments are able to transform the natural course of the disease (4). In addition, numerous chemotherapeutic treatment options induce undesirable side effects. The lack of safe and effective therapeutic options emphasizes the urgent requirement for the development of novel therapies. The ultimate goal is to identify an effective treatment that can extend the overall survival of patients with MDS.

Natural products have attracted considerable attention as anti-cancer agents over the past few years. Several of these compounds, including vincristine, paclitaxel and etoposide, have been tested and used in clinical treatment (8). Fucoidan, a complex sulphated polysaccharide natural product with a molecular weight of 5-627 kDa, was isolated from the cell wall matrix of brown seaweeds, which have been used in Traditional Chinese Medicine for nearly 2,000 years for the treatment of a wide variety of diseases, including thyroid disease, skin diseases, arteriosclerosis, hypertension and cancer (9-11). The anti-cancer effects of fucoidan are particularly promising (12). Previous studies reported that fucoidan effectively suppressed the proliferation and colony formation of cancer cells in vitro (13); furthermore, fucoidan inhibited metastasis and angiogenesis of Lewis lung adenocarcinoma 
and B16 melanoma xenografts in vivo (14). Natural products to attenuate or prevent the progression of carcinogenesis via three major mechanisms: Selective promotion of apoptosis in cancer cells, interference with the cell cycle and inhibition of angiogenesis and metastasis (14). However, whether fucoidan affects the apoptosis of MDS/AML cells has remained elusive.

The present study therefore examined the anti-cancer effects of fucoidan as well as its underlying molecular mechanisms of action in the human MDS/AML cell line SKM-1. For this purpose, the effects of fucoidan on the proliferation, cell cycle, apoptosis, generation of reactive oxygen species (ROS) and expression of apoptosis-associated genes in SKM-1 cells were assessed. The present study suggested that fucoidan may be a candidate drug for the treatment of MDS.

\section{Materials and methods}

Drugs and cell culture. Fucoidan was purchased from Sigma-Aldrich (St. Louis, MO, USA). The human MDS/AML cell line SKM-1 was provided by Professor Jianfeng Zhou (Department of Hematology, Tongji Medical College of Huazhong University of Science and Technology, Wuhan, China). Cells were maintained in RPMI-1640 (HyClone, Logan, UT, USA) supplemented with $10 \%$ heat-inactivated foetal bovine serum (FBS; Gibco-BRL, Invitrogen Life Technologies, Inc., Carlsbad, CA, USA) (15).

Cell counting kit (CCK-8) assay. The CCK-8 assay (cat. no. C0038; Beyotime Institute of Biotechnology, Shanghai, China) was performed to estimate the effects of fucoidan on the proliferation of SKM-1 cells. Cells were seeded $\left(3 \times 10^{4}\right.$ cells $\left./ \mathrm{ml}\right)$ in a 96-well plate in $100 \mu 1 \mathrm{RPMI}-1640$ containing $10 \% \mathrm{FBS}$ at $37^{\circ} \mathrm{C}$ in a $5 \% \mathrm{CO}_{2}$ incubator. After $24 \mathrm{~h}$, the medium was replaced with fresh medium containing various concentrations $(50,100,200,300,400$ and $500 \mu \mathrm{g} / \mathrm{ml})$ of fucoidan, and the cells were incubated for an additional 24 , 48 or $72 \mathrm{~h}$ at $37^{\circ} \mathrm{C}$ in the $5 \% \mathrm{CO}_{2}$ incubator. After incubation, the CCK-8 reagent $(10 \mu \mathrm{l})$ was added to each well, and the cells were incubated for $2 \mathrm{~h}$ at $37^{\circ} \mathrm{C}$ and $5 \% \mathrm{CO}_{2}$. The optical density (OD) values were measured at $450 \mathrm{~nm}$ using a microtiter plate reader (SpectraMax M5; Molecular Devices, LLC, Sunnyvale, CA, USA) (16). The results were expressed as the percentage of growth inhibition calculated according to the following formula: $\left(\mathrm{OD}_{\mathrm{Control}}-\mathrm{OD}_{\text {Experimental group }}\right) / \mathrm{OD}_{\text {Control }} \mathrm{x} 100 \%$.

Assessment of apoptosis. For the analysis of cell apoptosis, $2 \times 10^{5}$ SKM-1 cells were seeded into six-well plates in $1 \mathrm{ml}$ RPMI-1640 medium containing 10\% FBS and cultured overnight. Next, the medium was replaced with fresh RPMI-1640 or the same media containing $100 \mu \mathrm{g} / \mathrm{ml}$ fucoidan. After an additional incubation for $48 \mathrm{~h}$, the medium was discarded and the SKM-1 cells were washed twice in phosphate-buffered saline (PBS). Apoptosis was evaluated using Annexin V and propidium iodide (PI) staining (Beyotime Institute of Biotechnology) followed by flow cytometric analysis (FACSCalibur ${ }^{\mathrm{TM}}$; BD Biosciences, Franklin Lakes, NJ, USA) according to the manufacturer's instructions.

Cell cycle analysis. Cells were incubated with fucoidan $(100 \mu \mathrm{g} / \mathrm{ml})$ for $48 \mathrm{~h}$, harvested and washed twice with PBS.
Table I. Primers used for polymerase chain reaction.

\begin{tabular}{ll}
\hline Gene & \multicolumn{1}{c}{ Primers } \\
\hline Caspase3 & F: 5'-ATGACATCTCGGTCTGGT-3' \\
& R: 5'-AGAAACATCACGCATCAA-3' \\
Caspase8 & F: 5'-AAGGAAGCAAGAACCCAT-3' \\
& R: 5'-TGACCCTGTAGGCAGAAA-3' \\
Fas & F: 5'-TCCCATCCTCCTGACCAC-3' \\
& R: 5'-TCGTAAACCGCTTCCCTC-3' \\
Caspase9 & F: 5'-CCAAGCCTCTTCTTACTTCACC-3' \\
& R: 5'-CATCGTTCTGCCATCACTCA-3' \\
Actin & F:5'-CCACGAAACTACCTTCAACTAA-3' \\
& R: 5'-GTGATCTCCTTCTGCATCCTGT-3' \\
AKT & F: 5'-GCAAGGTGATCCTGGTGAA-3' \\
& R: 5'-TCGTGGGTCTGGAAAGAGTA-3'
\end{tabular}

F, forward; R, reverse.

The medium was discarded, the SKM-1 cells were washed twice with PBS and fixed with $70 \%$ alcohol for $4 \mathrm{~h}$. The cell cycle was determined by flow cytometry following PI staining of the nuclei.

Reverse transcription-quantitative polymerase chain reaction (RT-qPCR). Total RNA was isolated using RNAiso Plus (Takara Biotechnology, Otsu, Japan) following incubation of the cells with fucoidan $(100 \mu \mathrm{g} / \mathrm{ml})$ for $48 \mathrm{~h}$. Subsequently, cDNA was generated using a two-step RT-PCR kit (cat. no. RR037A; Takara Biotechnology). The quantitative PCR reaction was performed in a mixture with a total volume of $20 \mu \mathrm{l}$ and contained SYBR Premix Ex Taq $(10 \mu \mathrm{l}), 1 \mu \mathrm{l}$ of each primer $(10 \mu \mathrm{mol} / \mathrm{l}), 2 \mu \mathrm{l} \mathrm{cDNA}$ template and double distilled $\mathrm{H}_{2} \mathrm{O}(6 \mu \mathrm{l})$. A 7500 Real-Time PCR System (Applied Biosystems Life Technologies, Foster City, CA, USA) was used and the primers were designed using Primer 5 software (version 5; Jikai Co., Shanghai, China) and synthesized by Sangon Biotech (Shanghai, China; Table I). The thermocycling conditions were as follows: $95^{\circ} \mathrm{C}$ for $10 \mathrm{~min}, 40$ cycles of $95^{\circ} \mathrm{C}$ for $15 \mathrm{sec}, 65^{\circ} \mathrm{C}$ for $30 \mathrm{sec}$ and $72^{\circ} \mathrm{C}$ for $30 \mathrm{sec}$, and a final extension at $72^{\circ} \mathrm{C}$ for $10 \mathrm{~min}$. The $2^{-\Delta \Delta \mathrm{CT}}$ method was used to quantify the PCR products.

Western blot analysis. SKM-1 cells were treated with fucoidan $(100 \mu \mathrm{g} / \mathrm{ml})$ for $48 \mathrm{~h}$. Cells were harvested and washed twice with PBS, and the total protein was obtained after cell lysis using lysis buffer [components: $50 \mathrm{mM}$ Tris (pH 7.4), 150 mM NaCl, $1 \%$ Triton $\mathrm{X}-100,1 \%$ sodium deoxycholate, $0.1 \%$ SDS and sodium orthovanadate sodium fluoride, EDTA and leupeptin (Beyotime Institute of Biotechnology)]. Total protein was quantified using a BCA protein Assay kit (cat. no. P0012S; Beyotime Institute of Biotechnology) and $50 \mu \mathrm{g}$ protein was loaded per lane and separated using $10 \%$ SDS-PAGE, then transferred onto a polyvinylidene fluoride membrane with glycine transfer buffer (composed of $3.05 \mathrm{~g}$ Tris, $14.4 \mathrm{~g}$ glycine, $200 \mathrm{ml}$ methanol and $800 \mathrm{ml} \mathrm{H}_{2} \mathrm{O}$; Beyotime Institute of Biotechnology). After blocking with 5\% 
nonfat milk, the membrane was incubated with the following primary antibodies: Rabbit polyclonal Fas (cat. no. YT1676), rabbit polyclonal caspase-8 (cat. no. YT0660), rabbit polyclonal caspase-9 (cat. no. YT0664), rabbit polyclonal caspase-3 (cat. no. YT5204; Immunoway Biotechnology Co., Newark, DE, USA) all at a dilution of 1:500, for $12 \mathrm{~h}$ at $4^{\circ} \mathrm{C}$. Subsequently the membrane was incubated with the following secondary antibodies: Rabbit polyclonal anti- $\beta$-actin [dilution, 1:200 (cat.no. Ab119716); Abcam, Cambridge, UK], rabbit polyclonal phosphorylated-Akt [dilution, 1:100 (cat. no. Sc-135651); Santa Cruz Biotechnology, Inc., Dallas, TX, USA], rabbit polyclonal Akt [dilution, 1:100 (cat. no. Sc-8312); Santa Cruz Biotechnology, Inc.], all incubated at $4^{\circ} \mathrm{C}$ for $12 \mathrm{~h}$, as well as horseradish peroxidase-conjugated goat polyclonal immunoglobulin G [dilution, 1:7,000 (cat. no. ZDR-5036); ZSGB-BIO, Beijing, China] at $37^{\circ} \mathrm{C}$ for $2 \mathrm{~h}$. Protein bands were visualized using an enhanced chemiluminescence kit (cat. no. P0018; Beyotime Institute of Biotechnology) and analyzed using Quantity One software (version 4.6.2; Bio-Rad Laboratories, Inc., Hercules, CA, USA).

Measurement of intracellular ROS. The T-AOC detection assay kit (cat. no. S0119; Beyotime Institute of Biotechnology) was used to assess intracellular ROS production. SKM-1 cells were collected after incubation with fucoidan $(100 \mu \mathrm{g} / \mathrm{ml})$ for $48 \mathrm{~h}$ and labelled with $10 \mu \mathrm{M}$ dichloro-dihydro-fluorescein diacetate at $37^{\circ} \mathrm{C}$ in the dark for $30 \mathrm{~min}$. After washing the cells twice with RPMI-1640, the cellular fluorescence intensity was measured using a flow cytometer (excitation and emission wavelength, 488 and $525 \mathrm{~nm}$, respectively).

Statistical analysis. Values are expressed as the mean \pm standard deviation and one-way analysis of variance, Dunnett's test and independent samples t-test were performed to evaluate statistical significance. Statistical analyses were performed using SPSS version 20.0 (IBM SPSS, Armonk, NY, USA) and $\mathrm{P}<0.05$ was considered to indicate a statistically significant difference.

\section{Results}

Fucoidan inhibits the proliferation of SKM-1 cells in a doseand time-dependent manner. The present study first examined the effects of fucoidan on the proliferation of SKM-1 cells using a CCK-8 assay. SKM-1 cells were treated with various concentrations of fucoidan $(50,100,200,300,400$ and $500 \mu \mathrm{g} / \mathrm{ml})$ for 24,48 or $72 \mathrm{~h}$. The OD values were determined and the inhibition rate was calculated. The inhibition rate of SKM-1 cells treated with $50 \mu \mathrm{g} / \mathrm{ml}$ fucoidan for $24 \mathrm{~h}$ was $7.5 \pm 1.11 \%$, which increased to $43.4 \pm 2.72 \%$ at a concentration of $500 \mu \mathrm{g} / \mathrm{ml}$ fucoidan. Furthermore, the inhibition rate increased by $9.2 \%$ when the cells were exposed to $50 \mu \mathrm{g} / \mathrm{ml}$ fucoidan for $72 \mathrm{~h}$ (Fig. 1). The growth inhibition of SKM-1 cells by fucoidan was therefore concentration- and time-dependent.

Fucoidan induces apoptosis of SKM-1 cells and blocks the cell cycle in G1 phase. To determine whether the inhibitory effects of fucoidan on cell proliferation resulted from its induction of apoptotic cell death, SKM-1 cells treated with fucoidan $(100 \mu \mathrm{g} / \mathrm{ml})$ for $48 \mathrm{~h}$ were stained with Annexin V

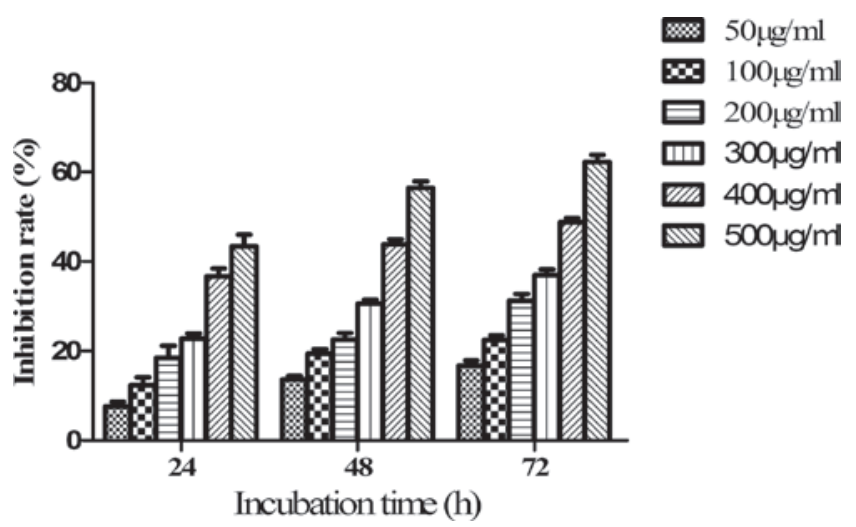

Figure 1. Inhibition rates of SKM-1 cells evaluated using the CCK-8 assay. SKM-1 cells were seeded in 96 -well plates at $3 \times 10^{3}$ cells/well. After $24 \mathrm{~h}$ of attachment, the cells were treated with fucoidan $(50,100$, $200,300,400$ or $500 \mu \mathrm{g} / \mathrm{ml}$ ) for 24,48 or $72 \mathrm{~h}$. The OD values were measured using the metabolic dye-based CCK- 8 assay. Values are expressed as the percent inhibition calculated according to the following formula: $\left(\mathrm{OD}_{\text {Control }}-\mathrm{OD}_{\text {Experimental group }}\right) / \mathrm{OD}_{\text {Control }} \mathrm{x} 100 \%$. Values are expressed as the mean \pm standard deviation $(n=3) . P<0.05$ between all concentrations of fucoidan at each time point. CCK-8, cell counting kit 8; OD, optical density.

and PI, and the apoptotic rate was detected using flow cytometry. The apoptotic rate of SKM-1 cells following treatment with fucoidan $(100 \mu \mathrm{g} / \mathrm{ml})$ was $28.2 \pm 0.94 \%$ compared with $16.4 \pm 0.75 \%$ in the control (Fig. $2 \mathrm{~A}$ ). The underlying mechanism of the anti-proliferative effects of fucoidan was further investigated by determining its effect on the cell cycle of SKM-1 cells. Following incubation with fucoidan $(100 \mu \mathrm{g} / \mathrm{ml})$ for $48 \mathrm{~h}$, cells were stained with PI and cell cycle analysis was performed using flow cytometry. The G1/G0-phase population in the fucoidan-treated group was $47.71 \pm 1.23 \%$ compared with $33.38 \pm 1.52 \%$ in the control group. However, the S-phase population decreased from $53.01 \pm 0.67$ to $44.94 \pm 0.99 \%$ and the $\mathrm{G} 2 / \mathrm{M}$-phase population decreased from $13.61 \pm 1.69$ to $7.36 \pm 1.35 \%$ following treatment with fucoidan compared with the control-group populations (Fig. 2B). These findings demonstrated that treatment with fucoidan increased the apoptotic rate and induced cell cycle arrest in G1/G0 phase.

Fucoidan induces apoptosis in SKM-1 cells via the extrinsic and intrinsic pathways. To gain further insight into the mechanism of fucoidan-induced apoptosis of SKM-1 cells, the expression of the apoptosis-associated molecules Fas, caspase-8, caspase- 9 and caspase- 3 was detected at the mRNA and protein level using RT-qPCR (Fig. 3A) and western blot analysis (Fig. 3B), respectively. The expression levels of the extrinsic pathway-associated molecules Fas and caspase- 8 as well as the intrinsic pathway-associated molecule caspase- 9 were gradually increased in response to fucoidan treatment $(100 \mu \mathrm{g} / \mathrm{ml}$ for $48 \mathrm{~h})$. In addition, the downstream effector caspase-3 was also activated.

Fucoidan blocks phosphoinositide-3 kinase (PI3K)/Akt signaling in SKM-1 cells. To investigate whether the PI3K/Akt signaling pathway is involved in fucoidan-induced apoptosis in SKM-1 cells, the mRNA levels of AKT were examined using RT-qPCR (Fig. 4A). The mRNA expression of AKT decreased by $0.2-0.5$ times compared with that in the normal control 

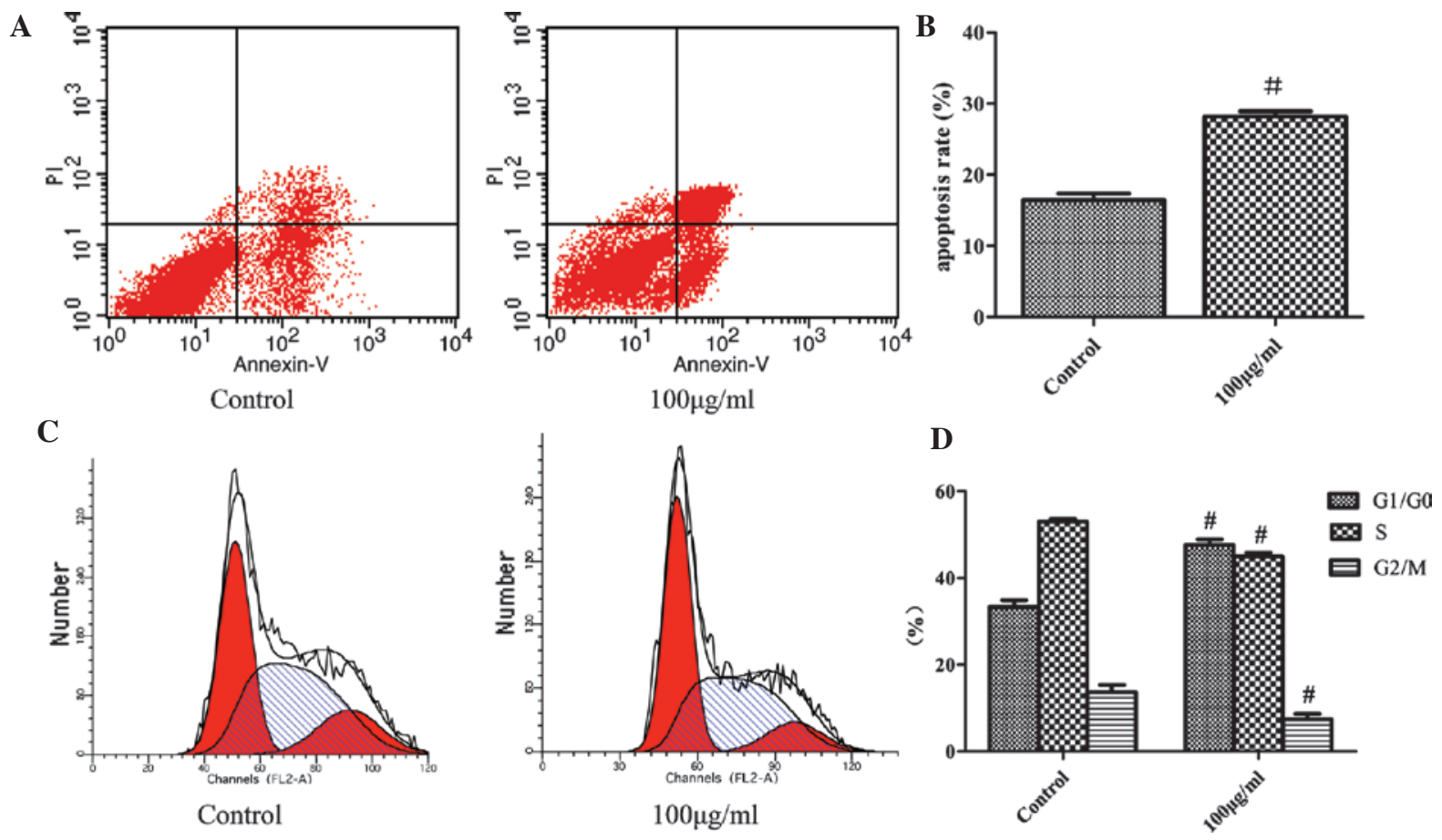

Figure 2. Flow cytometric analysis of the effects of fucoidan on apoptosis and cell cycle of SKM-1 cells. (A) Representative flow cytometry dot plots of SKM-1 cells treated with fucoidan $(100 \mu \mathrm{g} / \mathrm{ml})$ for $48 \mathrm{~h}$ and stained with Annexin V and PI. (B) Apoptotic rates obtained by quantification of Annexin V/PI staining. The apoptotic rate of SKM-1 cells treated with fucoidan $(100 \mu \mathrm{g} / \mathrm{ml})$ was $28.2 \%$ compared to $16.4 \%$ in the control group. (C) Representative cell cycle distribution of SKM-1 cells. In the fucoidan-treated group, the G1/G0-phase population was markedly increased compared with that in the control, while the S-phase and G2/M-phase populations were significantly decreased. (D) Quantified results of the cell cycle analysis. Values are expressed as the mean \pm standard deviation $(\mathrm{n}=3) .{ }^{\#} \mathrm{P}<0.05$ for $100 \mu \mathrm{g} / \mathrm{ml}$ fucoidan vs. control. PI, propidium iodide.
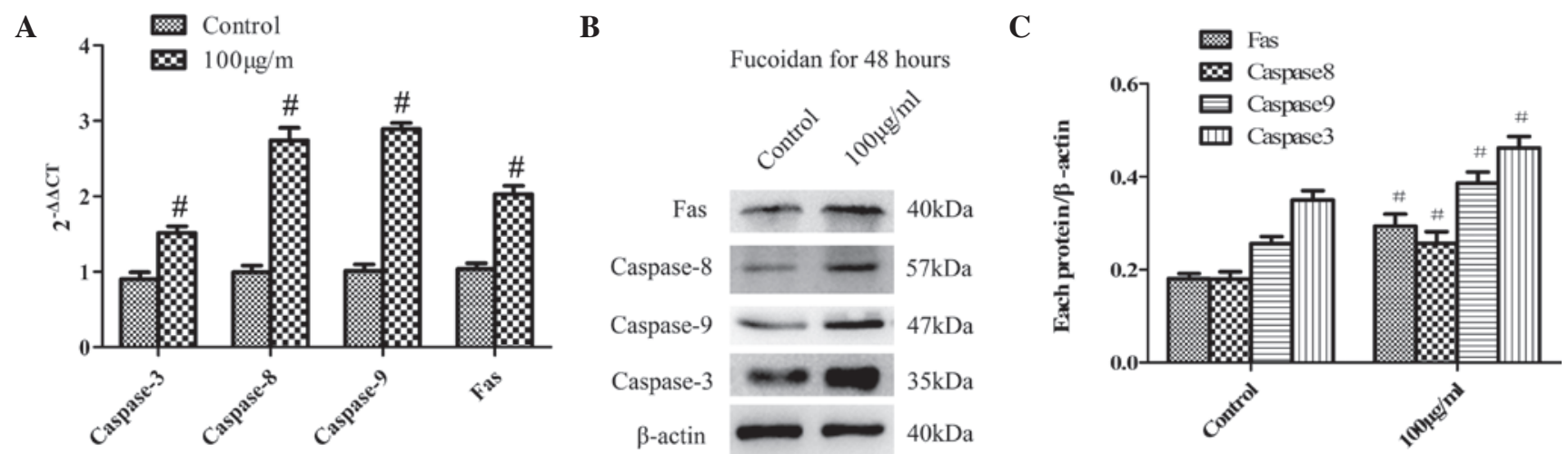

Figure 3. Polymerase chain reaction and western blot analyses were used to detect the expression of apoptosis-associated genes. SKM-1 cells were treated with fucoidan $(100 \mu \mathrm{g} / \mathrm{ml}$ ) for $48 \mathrm{~h}$. (A) The mRNA expression of Fas, caspase-3, caspase-8 and caspase-9 increased by 0.5-3 times compared with that in the normal control. (B) Representative western blots of Fas, caspase-3, caspase-8 and caspase-9. (C) Protein expression in SKM-1 cells was quantified by densitometric analysis of western blots of Fas, caspase-8, caspase- 9 and caspase- 3 normalized to $\beta$-actin. Values are expressed as the mean \pm standard deviation ( $n=3$ ). ${ }^{\#} \mathrm{P}<0.05$ for $100 \mu \mathrm{g} / \mathrm{ml}$ fucoidan vs. control.

group. Furthermore, the PI3K/Akt signaling pathway protein phospho-Akt and Akt were quantified using western blot analysis (Fig. 4B). The protein expression of phospho-Akt was decreased in SKM-1 cells treated with fucoidan $(100 \mu \mathrm{g} / \mathrm{ml}$ for $48 \mathrm{~h}$ ). These results indicated that fucoidan inactivated the PI3K/Akt signaling pathway.

Fucoidan increases intracellular ROS production. The present study investigated the generation of intracellular ROS to determine whether changes in ROS levels have a role in fucoidan-induced apoptosis in SKM-1 cells. Cells were incubated with $100 \mu \mathrm{g} / \mathrm{ml}$ fucoidan for $48 \mathrm{~h}$ and ROS were measured using flow cytometry. The mean value of ROS production was $264.3 \times 10^{3} / \mathrm{mg}$ protein in the fucoidan-treated group compared with $179.1 \times 10^{3} / \mathrm{mg}$ in the control group (Fig. 5). As ROS production was markedly enhanced in SKM-1 cells following fucoidan treatment, the generation of ROS may, at least in part, be the underlying molecular mechanism of the induction of cancer-cell apoptosis by fucoidan.

\section{Discussion}

Fucoidan, a complex sulphated polysaccharide extracted from brown seaweeds, has been shown to exhibit anti-cancer 

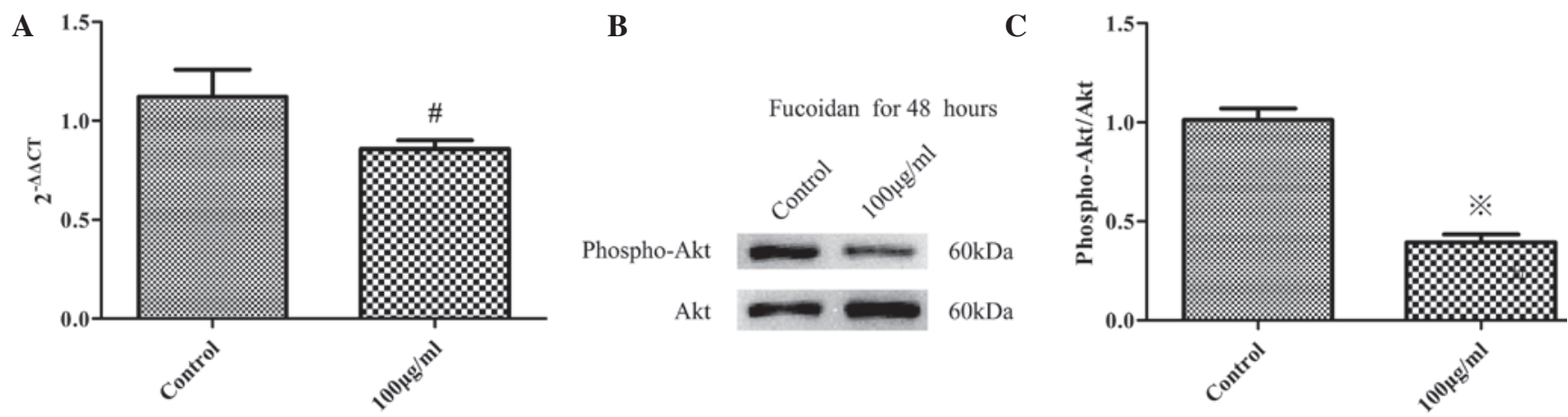

Figure 4. Polymerase chain reaction and western blot analyses were used to examine the expression of AKT and/or phospho-Akt in SKM-1 cells. (A) The mRNA expression of Akt decreased by 0.2-0.5 times compared with that in the control. (B) Representative western blots of phospho-Akt and Akt. (C) The protein expression of phospho-Akt vs. Akt in SKM-1 cells was quantified by densitometric analysis of the western blots. Values are expressed as the mean \pm standard deviation ( $\mathrm{n}=3$ ). ${ }^{*} \mathrm{P}<0.05$ for $100 \mu \mathrm{g} / \mathrm{ml}$ fucoidan vs. control.

A

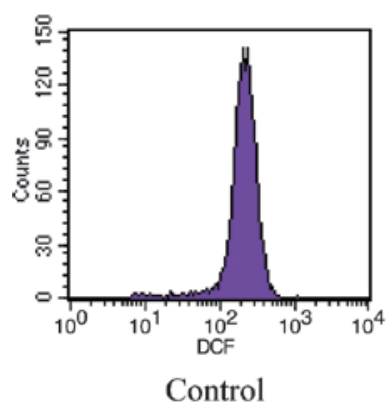

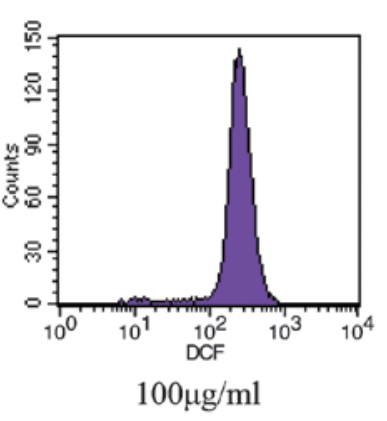

B

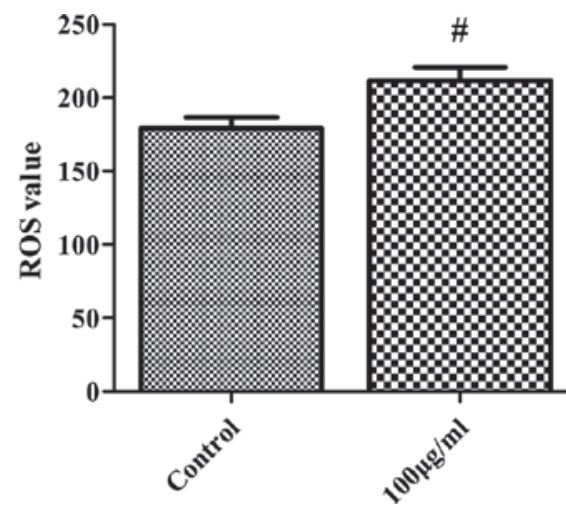

Figure 5. Effects of fucoidan on ROS levels in SKM-1 cells. Cells were treated with fucoidan (100 $\mu \mathrm{g} / \mathrm{ml})$ for $48 \mathrm{~h}$ and ROS generation was estimated using DCF and flow cytometric detection. (A) Representative flow cytometry histograms of ROS generation in SKM-1 cells. (B) Quantified ROS levels. Values are expressed as the mean \pm standard deviation $(\mathrm{n}=3) .{ }^{\#} \mathrm{P}<0.05100 \mu \mathrm{g} / \mathrm{ml}$ fucoidan vs. control. ROS, reactive oxygen species; DCF, dichloro-dihydro-fluorescein.

activity in a wide variety of tumour cell types and is therefore considered to be a promising novel candidate for cancer therapy with low toxicity to normal cells (17-20). In the present study, treatment with fucoidan inhibited the proliferation and induced apoptosis in the MDS/AML cell line SKM-1.

Previous studies have also indicated that fucoidan directly inhibited the proliferation of various cancer cell lines, including that of PC-3 cells at $10-200 \mu \mathrm{g} / \mathrm{ml}(21)$, MCF-7 cells at $82-820 \mu \mathrm{g} / \mathrm{ml}(22)$ and U937 cells at $20-100 \mu \mathrm{g} / \mathrm{ml}(23)$ where the incubation times were between 12 and $96 \mathrm{~h}$. In the present study, fucoidan inhibited the proliferation of SKM-1 cells at all studied concentrations $(50,100,200,300,400$, $500 \mu \mathrm{g} / \mathrm{ml}$ ) according to a CCK-8 assay. The inhibition rate of cells was $7.5 \pm 1.11 \%$ when the concentration of fucoidan was $50 \mu \mathrm{g} / \mathrm{ml}$, which increased to $43.4 \pm 2.72 \%$ at a concentration of $500 \mu \mathrm{g} / \mathrm{ml}$. Additionally, the inhibition rate increased by $9.2 \%$ when cells were exposed to $50 \mu \mathrm{g} / \mathrm{ml}$ fucoidan for $72 \mathrm{~h}$. Thus, fucoidan treatment inhibited the proliferation of SKM-1 cells in a dose- and time-dependent manner. Furthermore, flow cytometric analysis was performed to determine whether the inhibitory effects of fucoidan on cell proliferation resulted from apoptotic cell death and cell cycle arrest. The apoptotic rate of SKM-1 cells treated with fucoidan $(100 \mu \mathrm{g} / \mathrm{ml})$ for $48 \mathrm{~h}$ was $28.2 \%$ compared to $16.4 \%$ in the control group. In addition, following treatment with fucoidan, the G1/G0 phase population of SKM-1 cells was markedly increased compared with that in the normal control group, while the S-phase and G2/M-phase populations were significantly decreased. Therefore, flow cytometric analysis confirmed that the inhibition of proliferation by fucoidan was based on the induction of cell cycle arrest and apoptosis.

It is well known that apoptosis, the process of programmed cell death, has an important role in the normal development and differentiation of multicellular organisms; it is characterized by distinct morphological features and energy-dependent biochemical mechanisms (24). Apoptosis also serves as a critical protective mechanism against carcinogenesis caused by genetic mutations of normal cells, which may occur spontaneously or which may be induced by various stimuli or carcinogens. Fucoidan has been previously demonstrated to induce apoptosis in leukemia cells via B-cell lymphoma 2 and mitogen-activated protein kinase signaling (23). In the present study, the observed fucoidan-induced cell cycle arrest in G1/G0-phase, which may have been a response to cellular damage by ROS, may have caused the activation of apoptotic pathways, which was further confirmed by the increased apoptotic rate. Furthermore, the extrinsic pathway (death receptor-mediated) and the intrinsic pathway (mitochondrial mediated) of apoptosis represent two major pathways implicated in the induction of apoptotic cell death (25). Activation of caspases is a pivotal step in the extrinsic as well as the intrinsic apoptotic pathways and is triggered by signals from 
death factors, mitochondrial alterations or DNA damage due to external and/or internal insults (26). Fas, one of these death receptor factors, results in the clustering and formation of a death-inducing signaling complex. The results of the present study showed that treatment of SKM-1 cells with fucoidan increased the expression of Fas, which actives the extrinsic pathway. Further downstream in the apoptotic signaling cascade, initiator caspases, including caspase-8, significantly amplify the complex death-inducing signaling (24). The results of the present study showed that incubation of SKM-1 cells with fucoidan decreased the mRNA expression of AKT as well as the levels of phosphorylated AKT protein, therefore inhibiting the PI3K/Akt signaling pathway. The PI3K/Akt signaling pathway is another regulator of cell survival, cell growth and apoptosis, and inactivation of the PI3K/Akt signaling pathway inhibits the proliferation and induces the apoptosis of cancer cells by activating apoptotic signals through caspase-9 $(19,27)$. The present study further demonstrated that treatment of SKM-1 cells with fucoidan increased caspase-9 levels, which was likely to be mediated via decreases of PI3K/AKT signaling via the intrinsic pathway of apoptosis. In addition, activation of caspase- 3 was observed, which is a downstream effector of caspase- 8 and caspase- 9 . Upon its activation, the executioner caspase- 3 disassembles the cytoskeleton, leading to cell-morphological changes associated with apoptosis. These results indicated that fucoidan induced apoptosis of SKM-1 cells via activation of extrinsic as well as intrinsic apoptotic pathways.

Furthermore, ROS have a key role in oxidative stress and are generated as by-products of cellular metabolism, primarily in the mitochondria (28). The maintenance of an appropriate level of intracellular ROS is important for the maintenance of a redox balance and signaling associated with cellular proliferation (29). However, upon its overproduction, ROS can degrade cellular proteins, DNA and lipids, resulting in a state of oxidative stress (30). Previous studies have demonstrated that cancer cells can be effectively killed using natural products with the ability to increase intracellular ROS levels $(29,31)$. In the present study, fucoidan treatment of SKM-1 cells for $48 \mathrm{~h}$ caused a rapid accumulation of intracellular ROS . High levels of ROS increase the vulnerability of tumor cells to apoptosis; furthermore, ROS may have initiated the cellular damage signaling cascade, leading to cell cycle arrest and apoptosis. The observations of the present study suggested that the generation of ROS is involved in fucoidan-induced apoptosis in SKM-1 cells.

In conclusion, fucoidan, a natural product from the cell wall of brown seaweeds, caused cell cycle arrest and induced apoptosis via the activation of apoptotic pathways. Furthermore, the induction of apoptosis by fucoidan was likely to be associated with enhanced production of ROS. The results of the present study suggested that fucoidan is a promising candidate drug for the treatment of MDS.

\section{Acknowledgements}

The present study was supported by the National Natural Science Foundation of China (grant nos. 30971277 and 81250034), the Chongqing Natural Science Foundation (grant no. CSTC2009BB5070), the Chongqing Health Bureau
Foundation (grant no. 2013-2-023) and the Chongqing Education Commission Foundation (grant no. 2013).

\section{References}

1. Foran JM and Shammo JM: Clinical presentation, diagnosis and prognosis of myelodysplastic syndromes. Am J Med 125 (Suppl 7): S6-S13, 2012

2. Zhou T, Hasty P, Walter CA, Bishop AJ, Scott LM and Rebel VI: Myelodysplastic syndrome: An inability to appropriately respond to damaged DNA? Exp Hematol 41: 665-674, 2013.

3. Pilo F, Di Tucci AA, Dessalvi P, Caddori A and Angelucci E: The evolving clinical scenario of myelodysplastic syndrome: The need for a complete and up to date upfront diagnostic assessment. Eur J Intern Med 21: 490-495, 2010.

4. Li JN: Myelodysplastic syndrome hematopoietic stem cell. Int J Cancer 133: 525-533, 2013.

5. Garcia-Manero G: Myelodysplastic syndromes: 2012 update on diagnosis, risk-stratification and management. Am J Hematol 87: 692-701, 2012.

6. Ma X: Epidemiology of myelodysplastic syndromes. Am J Med 125 (Suppl 7): S2-S5, 2012.

7. Voso MT, Santini V, Finelli C, Musto P, Pogliani E, Angelucci E, Fioritoni G, Alimena G, Maurillo L, Cortelezzi A, et al: Valproic acid at therapeutic plasma levels may increase 5-azacytidine efficacy in higher risk myelodysplastic syndromes. Clin Cancer Res 15: 5002-5007, 2009.

8. Zhang Z, Teruya K, Eto H and Shirahata S: Induction of apoptosis by low-molecular-weight fucoidan through calcium- and caspase-dependent mitochondrial pathways in MDA-MB-231 breast cancer cells. Biosci Biotechnol Biochem 77: 235-242, 2013.

9. Nobili S, Lippi D, Witort E, Donnini M, Bausi L, Mini E and Capaccioli S: Natural compounds for cancer treatment and prevention. Pharmacol Res 59: 365-378, 2009.

10. Liu L, Heinrich M, Myers S and Dworjanyn SA: Towards a better understanding of medicinal uses of the brown seaweed sargassum in traditional Chinese medicine: A phytochemical and pharmacological review. J Ethnopharmacol 142: 591-619, 2012.

11. Zhu C, Cao R, Zhang SX, Man YN and Wu XZ: Fucoidan inhibits the growth of hepatocellular carcinoma independent of angiogenesis. Evid Based Complement Alternat Med 2013: 692549, 2013.

12. Yang L, Wang P, Wang H, Li Q, Teng H, Liu Z, Yang W, Hou L and Zou X: Fucoidan derived from Undaria pinnatifida induces apoptosis in human hepatocellular carcinoma SMMC-7721 cells via the ROS-mediated mitochondrial pathway. Mar Drugs 11: 1961-1976, 2013.

13. Ermakova S, Sokolova R, Kim SM, Um BH, Isakov V and Zvyagintseva T: Fucoidans from brown seaweeds Sargassum hornery, Eclonia cava, Costaria costata: Structural characteristics and anticancer activity. Appl Biochem Biotechnol 164: 841-850, 2011.

14. Fulda S: Modulation of apoptosis by natural products for cancer therapy. Planta Med 76: 1075-1079, 2010.

15. Wang L, Luo J, Nian Q, Xiao Q, Yang Z and Liu L: Ribosomal protein S14 silencing inhibits growth of acute myeloid leukemia transformed from myelodysplastic syndromes via activating p53. Hematology 19: 225-231, 2013.

16. Thinh PD, Menshova RV, Ermakova SP, Anastyuk SD, Ly BM and Zvyagintseva TN: Structural characteristics and anticancer activity of fucoidan from the brown alga sargassum mcclurei. Mar Drugs 11: 1456-1476, 2013.

17. Xue M, Ge Y, Zhang J, Wang Q, Hou L, Liu Y, Sun L and Li Q: Anticancer properties and mechanisms of fucoidan on mouse breast cancer in vitro and in vivo. Plos One 7: e43483, 2012.

18. Teruya T, Konishi $\mathrm{T}$, Uechi S, Tamaki $\mathrm{H}$ and Tako M: Anti-proliferative activity of oversulfated fucoidan from commercially cultured Cladosiphon okamuranus Tokida in U937 cells. Int J Biol Macromol 41: 221-226, 2007.

19. Boo HJ, Hong JY, Kim SC, Kang JI, Kim MK, Kim EJ, Hyun JW, Koh YS, Yoo ES, Kwon JM and Kang HK: The anticancer effect of fucoidan in PC-3 prostate cancer cells. Mar Drugs 11: 2982-2999, 2013.

20. Xue M, Ge Y, Zhang J, Liu Y, Wang Q, Hou L and Zheng Z: Fucoidan inhibited $4 \mathrm{~T} 1$ mouse breast cancer cell growth in vivo and in vitro via downregulation of $\mathrm{Wnt} / \mathrm{beta}$-catenin signaling. Nutr Cancer 65: 460-468, 2013. 
21. Boo HJ, Hong JY, Kim SC, Kang JI, Kim MK, Kim EJ, Hyun JW, Koh YS, Yoo ES, Kwon JM and Kang HK: The anticancer effect of fucoidan in PC-3 prostate cancer cells. Mar Drugs 11: 2982-2999, 2013

22. Zhang Z, Teruya K, Eto H and Shirahata S: Fucoidan extract induces apoptosis in MCF-7 cells via a mechanism involving the ROS-dependent JNK activation and mitochondria-mediated pathways. PLoS One 6: e27441, 2011.

23. Park HS, Hwang HJ, Kim GY, Cha HJ, Kim WJ, Kim ND, Yoo YH and Choi YH: Induction of apoptosis by fucoidan in human leukemia U937 cells through activation of p38 MAPK and modulation of Bcl-2 family. Mar Drugs 11: 2347-2364, 2013

24. Elmore S: Apoptosis: A review of programmed cell death. Toxicol Pathol 35: 495-516, 2007.

25. Senthilkumar K, Manivasagan P, Venkatesan J and Kim SK: Brown seaweed fucoidan: Biological activity and apoptosis, growth signaling mechanism in cancer. Int J Biol Macromol 60: 366-374, 2013

26. Budihardjo I, Oliver H, Lutter M, Luo X and Wang X: Biochemical pathways of caspase activation during apoptosis. Annu Rev Cell Dev Biol 15: 269-290, 1999.
27. Jin S, Pang RP, Shen JN, Huang G, Wang J and Zhou JG: Grifolin induces apoptosis via inhibition of PI3K/AKT signalling pathway in human osteosarcoma cells. Apoptosis 12: 1317-1326, 2007.

28. Quan Z, Gu J, Dong P, Lu J, Wu X, Wu W, Fei X, Li S, Wang Y, Wang J and Liu Y: Reactive oxygen species-mediated endoplasmic reticulum stress and mitochondrial dysfunction contribute to cirsimaritin-induced apoptosis in human gallbladder carcinoma GBC-SD cells. Cancer Lett 295: 252-259, 2010.

29. Pelicano H, Feng L, Zhou Y, Carew JS, Hileman EO, Plunkett W, Keating MJ and Huang P: Inhibition of mitochondrial respiration: A novel strategy to enhance drug-induced apoptosis in human leukemia cells by a reactive oxygen species-mediated mechanism. J Biol Chem 278: 37832-37839, 2003.

30. Yang L, Wang P, Wang H, Li Q, Teng H, Liu Z, Yang W, Hou L and Zou X: Fucoidan derived from Undaria pinnatifida induces apoptosis in human hepatocellular carcinoma SMMC-7721 cells via the ROS-mediated mitochondrial pathway. Mar Drugs 11: 1961-1976, 2013.

31. Huang P, Feng L, Oldham EA, Keating MJ and Plunkett W: Superoxide dismutase as a target for the selective killing of cancer cells. Nature 407: 390-395, 2000. 